\title{
URBAN RENEWAL PLANNING IN GERMAN CITIES - A GOVERNANCE ANALYSIS
}

\section{Carola NEUGEBAUER}

\author{
RWTH Aachen, Germany \\ carola.neugebauer@rwth-aachen.de
}

\begin{abstract}
The European Union and Germany strive for a "green and just Europe" with a climate-neutral building stock, net zero land consumption and cities of social cohesion and cultural identity. Thus, urban renewal as the protection and cautious re-modelling of socio-material urban fabrics re-gains topicality. Urban renewal is neither a new nor an easy mode of urban development: West Germany experienced the first heydays of urban renewal planning in 1960s and 70s; big constructions works triggered civil protests and spurred institutional changes, namely the introduction of citizen participation in planning. Since then, the planning and local political institutions have continued to change oscillating between neoliberal and 'citizen democratic reforms'. So far, however, the German planning research has ignored these changes and the evolving experiences of urban renewal.

This paper steps in here: It aims at a critical review of the local practices of renewal planning in German cities today. Starting from the governance concept, the paper reveals key characteristics of and interdependencies among the local stakeholder groups in urban renewal - i.e. planners, politicians, citizens and activists, private entrepreneurs. It shows (1) how the formal political and planning institutions pre-frame the actors' opportunities and interdependencies, and how they use leeway differently due to specific informal institutions. The paper (2) points at the tight and critical interdependency between the local political bodies and the planning departments, which differs importantly from some Eastern European contexts. Finally, the paper reveal (3) some new challenges that are the un-explored local effects of citizen participation and ppp-cooperation in German renewal planning today: It becomes evident that participatory and cooperative renewal planning is still a demanding learning process in Germany without easy nor final receipts.
\end{abstract}

Key words: urban renewal planning, urban governance, planning and participation institutions, alliances of stakeholders, urban planning conflicts, Germany.

DOI: https://doi.org/10.17721/2413-7154/2021.85.23-37

UDC: $911.3: 711.4$

Received: March 1, 2021.

Accepted: March 24, 2021.

\section{ПЛАНУВАННЯ РЕНОВАЦІЇ МІСТ У НІМЕЧЧИНІ - АНАЛІЗ УПРАВЛІННЯ Карола НОЙГЕБАУЕР}

Рейнсько-Вестфальський технічний університет Аахена, Німеччина carola.neugebauer@rwth-aachen.de

\begin{abstract}
Анотація: Європейський Союз та Німеччина прагнуть до розбудови "зеленої та справедливої Європи": кліматичної нейтральності будівельного фонду, мінімізації нового залучення земель під будівництво, досягнення високого рівня соціальної згуртованості та потужної культурної ідентичності міст. За таких умов знову набувають актуальності практики оновлення міст для захисту та збалансованого перетворення соціального та матеріального міського середовища. Оновлення міст не $\epsilon$ ні новим, ні простим інструментом міського розвитку. Зокрема, Західна Німеччина пережила перший розквіт практик міської реновації у 1960-х та 1970-х, причому великі будівельні проєкти стали каталізаторами громадянських протестів та стимулювали інституційні зміни, а саме - запровадження громадянської участі у міському плануванні. 3 тих пір як планувальні, так і місцеві політичні інститути продовжували змінюватися, коливаючись між неоліберальною політикою та «демократичними реформами». Проте, станом на сьогодні ці зміни та досвід оновлення німецьких міст не були належним чином відрефлексовані у наукових дослідженнях.

Метою цієї статті $\epsilon$ критичний огляд сучасних місцевих містобудівних практик в галузі міського оновлення в Німеччині. Зокрема, на початку подано аналіз концепції управління міським розвитком та оновленням міст Німеччини, а також розкрито ключові характеристики та взаємозв'язки між місцевими групами зацікавлених сторін в процесі оновлення міст - фахівців з міського планування, політиків, звичайних громадян, громадських активістів, приватного бізнесу. Таким чином стає можливою демонстрація (1) впливу формальних політичних та містобудівних інститутів на можливості та взаємозалежність суб'єктів процесу планування та відмінності у використанні ними специфічних неформальних інститутів та інструментів. Також в статті (2) показано жорстку та критичну взаємозалежність місцевих політичних інституцій та містобудівних департаментів, що $\epsilon$ істотною відмінністю ситуації в Німеччини від деяких країн Східної Європи. Насамкінець, у статті розкрито (3) деякі нові виклики, які постають в процесі планування оновлення міст Німеччини в результаті невивчених локальних ефектів громадської участі та публічно-приватного партнерства. Таким чином, стає очевидним, що досвід планування у сфері реновації міст у Німеччині досі потребує свого детального вивчення та не містить ні простих, ні остаточних рецептів.
\end{abstract}

Ключові слова: планування міського оновлення, міське управління, інститути міського планування та партисипації, альянси стейкхолдерів, містобудівні конфлікти, Німеччина.

(C) Carola Neugebauer 


\section{Introduction}

Urban renewal means the appreciation and careful use of the existing socio-cultural and material resources in urban space; it gains importance and topicality in view of the climate change and the polarization of society and spaces (Territorial Agenda, 2030). The latter increase the pressure towards sustainable cities and a "green and just Europe" (ibid.; EU council, 2020). Urban renewal as the protection and cautious re-modelling of urban fabrics thus needs critical review and attention in practice and research, in particular thecurrent conflicts and challenges.

The German policy strives for a climate-neutral building stock and a net zero land consumption based on circular land management by 2050 (BMU, 2016). Urban renewal helps to reducethe exploitation of new resources such as energy, building materials and land (ibid.). The German policy thus urges for the protection and adaptation of existing urban structures and housing stocks, based on the stock's comprehensive (re)assessment regarding material-energetic life cycles and socio-cultural and ecological livelihoods. Urban renewal is a crucial part of the envisioned, broader socio-ecological transformation.

The aspired transformation calls for the critical review of the current practices and fundamentals of urban renewal planning. The European key documents of territorial policy - the Territorial Agenda 2030 and New Leipzig Charter - point to the decisive role of "governance quality" (Territorial Agenda, 2030: 2; cf. EU Council, 2020). They call for "place-based approaches" in planning that build on evidences, spatial and sectoral integration, subsidiarity and the "cooperation and coordination within society" (Territorial Agenda, 2030: 4). The latter means the involvement of citizens and civil society, private entrepreneurs and experts.Thus, urban renewal planning serving to the great socio-ecological transformation is relevant by content and by process too.

In West Germany, urban renewal planning has a long, conflictual history starting in the late 1960s and 1970s. Rehabilitation projects demolished historic urban districts at large extent (called Kahlschlagsanierung). It spurred the criticism among intellectuals and citizens of the insensitive, benefitdriven and technocratic mode of planning (cf. Mayer, 2010). Urban renewal became a subject of formal regulation and urban policy. However, still today urban renewal planning causes public contestation, raising critical questions: What is the state of urban renewal planning in Germany today - in particular of the 'cooperation and coordination within society'? What are the points, which call for (more) critical attention in pursue of a 'just and green city'?

The paper addresses these questions. It aims at the critical review of German renewal planning as a mode of urban governance what broadens the view: Instead of looking at the professional urban planners only, I am interested in the interplays of actors in renewal planning. They involve the public authorities - the planners and politicians, the citizens and activists as well as private entrepreneurs (investors, developers). I seek:

(1) to characterize the key stakeholdersin urban renewal with regard to their concepts, practices, and opportunities in planning;

(2) to reveal thesystemic interdependencies between them with an emphasis on the formal and informal institutions, and

(3) to point on critical moments that deserve practical and scholarly debate and exploration - also in Ukraine today.

The paper builds on primary research in three German cities as well as on secondary data ${ }^{1}$ that I present and discuss in four observations about each stakeholder group. The final part summarizes the essentials of German renewal governance and the critical moments for further debate. However first, I remind of the conceptual basis of this paper and introduce the German context. Moreover, I present two stories of conflictual renewal planning in the West German city of Bonn that serve as examples and entry points to the general observations.

\section{The concept of urban governance}

Since the 1990's scholars look through the theoretical lens of governance at urban planning (Cruz et al. 2019). In this vein, urban planning constitutes one mode of urban governance. This conceptual perspective requires considering urban planning not exclusionary limited to the realm of planning professionals within the city administration, but as a process, which involves a variety of actors. Rather than to question urban planning as a field of state power and technical expertise only, where architects and planners have a primary voice and bureaucrats steer the process, a wide range of economic, civic and political actorscalls for consideration. The concept of urban governance reminds of three aspects that are constitutive to the present paper's analysis:

${ }^{1}$ The primary data stems from the tri-national, comparative research project "Shifting paradigms - Towards participatory and effective planning" (TRIPAR). The interdisciplinary project (funded by the German Volkswagen Foundation) run from 2017-2019 with a one-year extension in 2020. The first stage (2017-2019) comprised the in-depth research of urban renewal planning in selected German, Ukrainian and Russian case cities. In Germany, the city of Bonn was selected as case. A systematic analysis of local newspaper, covering the last 20 years, revealed reports several conflicts related to urban renewal projects and planning. The two most debated conflicts were selected for in-depth analysis (the Railway station square and the Viktoriakarree). The in-depth analysis comprised document analysis (planning documents, protocols etc.) as well as interviews $(\mathrm{N}=25)$ with the involved local stakeholders, i.e. representatives of the local civil society, public authorities (administration, policy) and private economy (investors, property owner, renters). The second stage of research (2020) is still running. It looks at two further cities in each national context - the cities of Arnsberg and Essen in German Federal State of North Rhine Westphalia. Similar to Bonn, we carried out newspaper analysis and local interviews. Apart from this primary data, the paper refers to secondary data, namely to German studies on local (urban) governance. Noteworthy are the studies of Tausendpflug/ Vetter (2017) - a randomized survey of 720 deputies in 28 German cities as well as Heinelt et al. (2018) - a survey among German mayors. The secondary data serves to the broader contextualization and critical reflection of the own primary data. 
First, planning institutions - in terms of formal regulations and laws as well as shared concepts and routines - structure the opportunities andinteractions among the different stakeholders in urban renewal planning. They matter for planning processes and results, and constantly raise the question how power imbalances are managed for whose benefit (cf. Sorensen 2017).

Second, urban planning is per sepolitical, since it comes up with decisions on territorial land-use and transformation, which weigh stakeholders' interests over each other (Fainstein, 2016). Consequently, urban planning in Europe is linked to local political systems, which arebased on models of parliamentary democracy. The political institutions structure interdependencies among the stakeholders, which need consideration in planning analysis too.

Third, scholars sensitize for the evolutionary nature of governance. In this vein, planning (re-) produces socio-material results, stakeholder arrangements and institutions that are bound to specific, e.g. socioeconomic contexts in time and space. Planning practices and institutions are locally specific and evolve over time.

\section{The German context}

Urban renewal planning in Germany is bound to a complex set of formal institutions for local planning and politics. The renewal planning defines the land-use rules for the functional and material transformation of a specific territory. The German planning code - the Baugesetzbuch $(B a u G B)$ - defines a set of planning instruments and rules how to do so.

\section{Formal planning institutions}

The instruments of statutory land-use planning are highly formalized. They are legally binding to everyone and constitute the basis for building permits. Similar to many Central and Eastern European countries, they are the backbone of the German local planning system. The general land-use plan (Flächenutzungsplan) integrates all sectoral planning (e.g. transportation, nature and culture preservation) and defines functional zones for development such as residential or recreational areas at the city level. The detailed land-use plan governs the development of the particular land plots; it defines type and degree of construction. The German legislation distinguishes three procedures of detailed land-use planning. There is (1) the statutory detailed land-use plan (Bebaaungsplan, $\S 9$ BauGB), (2) the ppp ${ }^{2}$-based detailed land-use plan (Vorhabenbezogener Bebaunnsplan, $\$ 12 \mathrm{Bau} G B$ ) and (3) the accelerated detailed land-use planning (Vereinfachtes Bebauungsplanverfahren, $\$ 13$ BauGB). While the first represents the standard procedure with the first-hand checking of all environmental and civic concerns, the ppp-based planning hands over the definition of the project idea and planning agenda to the investor ${ }^{3}$. The accelerated detailed land-use planning allows the forgoing on the environmental impact assessment as well as a reduced form of citizen participation ${ }^{4}$. Apart from that, the paragraph $\S 34$ of the Baugesetzbuch substantiates a legal claim for building permits in largely built-up areas, given that no detailed land-use plan is in force and that the new construction project fits the close urban fabric. The fitting is assessed along a set of criteria; the urban planning department then grants the building permit without any further checkingand citizen participation.

Voluntary planning instruments may complement the statutory planning at all levels. Strategic and master plans, for example, can add tothe statutory land-use planswith new analytical contents (e.g. cadaster of vacancies, micro-climates) and new cooperative tools for envisioning the city's future. Design competitions and real estate tenders are examples of the latter. They are meant to advance design ideas and the process of project implementation respectively. The German planning legislation allows voluntary instruments, but regulates neither their processes nor contents in detail. Various recommendations of different scope, quality and purpose display experiences and learning processes with these instruments.

Finally, the statutory and voluntary instruments of planning are linked to mandatory and voluntary tools of stakeholder involvement. The German planning code requires a two-staged citizen participation process for any statutory land-use plan $(\operatorname{Bau} G B \xi 3)^{5}$. Voluntary tools of citizen participation-such as citizen workshops (Bürgerwerkstatt), future labs (Zukunftsforum) and many more - may complement all planning. Moreover, additional professional expertise may be involved in planning, complementing the obligatory coordination among the different departments within the city administrations. The advisory board for urban design (Gestaltungsbeirat) is a widespread example thereof: invited, external experts advise on the projects of urban renewal. But again, in contrast to the mandatory tools, the local decision-makers in policy and administration own great leeway here: they decide, when, how and why these voluntary tools of stakeholder involvement are used.

\footnotetext{
${ }^{2}$ The ppp is the abbreviation for "public private partnership".
}

${ }^{3}$ The ppp-based detailed planning builds on the investor's interest in construction on a plot, where a detailed land-use is missing. If the investor's construction idea is in line with the superordinate planning, a ppp-contract regulates among the partners the costs and modes of detailed planning and, if wanted, of project realization. The environmental impact assessment and the citizen participation are still mandatory and the final plan is approved by the city council, but the contract itself is not subject of parliamentary control.

${ }^{4}$ The accelerated detailed-planning is allowed only in built-up areas ( $\$ 13 \mathrm{a}$ BaugGB). It relies on the assumption that all the environmental and civic concerns have been checked at the superordinate planning level. The reduction of citizen participation refers to the possibility to forego the early-stage participation (see below: $\$ 3(1)$ ) as well as to replace the 2 nd stage of public hearing (see below: $\$ 3$ (2)) by another mode of citizen involvement

${ }^{5}$ The $\S 3$ of the planning code (BauGB) prescribes citizen participation in two stages. First, there is early stage discussion ( $\$ 3(1)$ ): 'The public shall be informed publicly as early as possible about the general objectives and purposes of the planning, substantially different solutions that may be considered for the redesign or development of an area, and the likely effects of the planning. The public shall be given the opportunity to comment and discuss the matter.' At the second stage, there is the public hearing ( $\$ 3(2))$, where all planning documents including explanations and alternatives for planning are presented to the citizens. All citizens' written feedback has to be considered and answered in a written form. 


\section{Formal political institutions}

Urban renewal planning in Germany is linked to the local political system (Fig. 1). The prototype process of statutory land-use planning reveals this nexus: The city administration, in particular the planning department, elaborates and coordinates the urban planning process, and the city council decides on launching and approving the planning. Several committees of the city council advice and in some cases guide its decisions. In the German city of Bonn, for example, the Committee for Planning (Bauausschuss) decides if land-use planning processes should start or not. The Committee for Citizens' Affairs collects, forwards and moderates the questions and complaints that individuals send to the city council. Each committee consists of representatives of the council (mostly according to the seat distribution among the political parties), representatives of the city administration and of citizens appointed by the political parties. The city mayor heads the city administration and city council. The citizens directly elect both, the mayor and the city council every five years. The city is politically and financially independent, although it has to follow the general rules of regional planning as well as the laws of the respective German federal state to whom it belongs.

According to political regulations of the German Federal States (Kommunalverordnung), residents can also directly intervene in local political issues such as urban renewal planning. Figure 1 shows the two-staged instrument of petition and referendum: If a petition is successful, the referendum allows the citizens to directly voteon the local issue in question and thus to control directly the city council and mayor ${ }^{6}$. So far, German municipalities have rarely faced referenda, but the number is growing and topics of urban renewal are at the top (cf. Vetter et al., 2016). The opportunity for referenda is quite new in German legislation. It reminds ofthe incremental, but important changes in the German planning and political systems during the last decades.

\section{Formal institutional changes}

First of all, the urban planning system has undergone important changes since the 1970's. In the late 1960's and 1970's leftist citizens and intellectuals pushed the public authorities towards more collaborative and stock-sensitive forms of planning (Mayer, 2000). They required turning away from growth-oriented big projects towards sensitive urban renewal and heritage protection. Moreover, they urged for a shift away from the omniscient perspective of the public authorities towards citizen participation. Legislative changes followed the protest movement. The early-stage citizen participation (today $\S 3 \mathrm{BauGB}$ ) as well as the possibility to protect the urban fabric and milieu at the local level (Erhaltungssatzung and Milieuschutz) were introduced in 1976 (Schmidt-Eichstaedt et al., 2014: 78). A bit later in view of the economic crisis since 1978, planning instruments were introduce that strengthen entrepreneurship in urban planning, namely the ppp- based detailed-land use planning (Vorhabenbezogener Bebauungsplan) in 1990 and further forms of urban planning contractualism in 1993 (Städtebauliche Verträge). The accelerated detailed land-use plan (Vereinfachtes Bebauungsplanverfahren §13a) was introduced in 2006 (Schmidt-Eichstaedt et al., 2014: 78 ) in order to counterbalance the increased complexity of planning due to the environmental assessments and citizen participation.

Today, some scholars refer to these institutional changes as the shift from the modernist planning paradigm - i.e. the expert-based, state-governed and sectoral planning - to the communicative-collaborative planning paradigm based on more multi-lateral communication and informal collaboration (Healey, 1997). Others spot herein the "contradictions of neoliberal planning" (Tasan-Kok, 2012), i.e. the promotion of civic engagement, democracy and effectiveness in planning on the one hand, and - though by modified practices and instruments - the maintenance of the established power hierarchies in urban development on the other hand.

Since the early 1990s, also the local political institutions of parliamentary democracy have witnessed important changes: The last parliament of the GDR introduces far-reaching elements of direct democracy to the municipal level (Vetter, 2009). The reform ideas spread out to all German federal states after reunification. They include the direct election of the city mayor, the opportunity for petition and referenda, the possibility of open electoral lists as well as the lowering or abolition of percentage hurdles for city council elections. The political scientist Angelika Vetter acknowledges these changes as the shift from "local party democracy" towards "local citizens democracy" (Vetter, 2009: 127) that upgrades the citizens' voice in the local parliamentary democracy.

Both formal institutional shifts - towards 'citizen democracy' and participatory, liberalized urban planning - emerged incrementally in West Germany. Triggered by economiccrisis and political failures (cf. Vetter, 2009), they propagated improvements of the performance (effectiveness and quality) and legitimacy (representativeness and trust) of urban governance (Vetter et al., 2013: 257; cf. Eckardt et al., 2009).

4. Two conflict stories of urban renewal planning in the city of Bonn

The following review of two conflictual projects in Bonn exemplify how these formal planning and political institutions play out on the ground. The conflict stories shed light on both, the general challenges and patterns of renewal governance in German cities as well as on the specificities of urban renewal planning in Bonn. Bonn represents a prosperous big city of 320.000 inhabitants in the West German Federal State of North RhineWestphalia.

The two conflicts in Bonn emerged around attempts to reconstruct parts of the existing urban fabric. In the

\footnotetext{
${ }^{6}$ Angelika Vetter (2009: 139) explains: „Local referendums in Germany are divided into two steps. First, there is an initiative stage (Bürgerbegehren) in which citizens petition the referendum. Different quorums of necessary signatures facilitate or hinder the success of the initiative. Only when the first stage is passed is the decision taken by popular vote in the second step (Bürgerentscheid), again with different quorums of yes voters in all eligible voters". Though referenda could be used for the direct and pro-active agenda setting by citizens, if linked to additional forms of civic participation at the stage of preparing the referenda, this is rarely the case in Germany.
} 
first conflict case, a lively inner-city historical quarter called Viktoriakaree should be transformed into more profitable real estate by an international developer. The second conflict story refers to the sustained citizen opposition to the city's plans to redevelop the railway station square and its adjacent buildings. Table 1 displays a brief summary of the renewal projects under scrutiny. The two conflicts differ in the duration, but also match on some points. They are reconstructed, based on the analysis of the media reports and relevant documents (cf. Neugebauer et al., 2021).
Bonn: An inner-city neighborhood under threat (Viktoriakarree)

The conflicts in Bonn unfolded in the inner city. The case of the Viktoriakarree concerns a vibrant quarter close to the city's university that comprised housing, small shops, cultural amenities, and a public swimming hall of the 1960s under monument protection. Discussions about the re-development of the area germinated from the City Council's decision in 2007 to close the swimming hall. Consequently, several informal planning concepts were developed that foresaw to strengthen the retail function

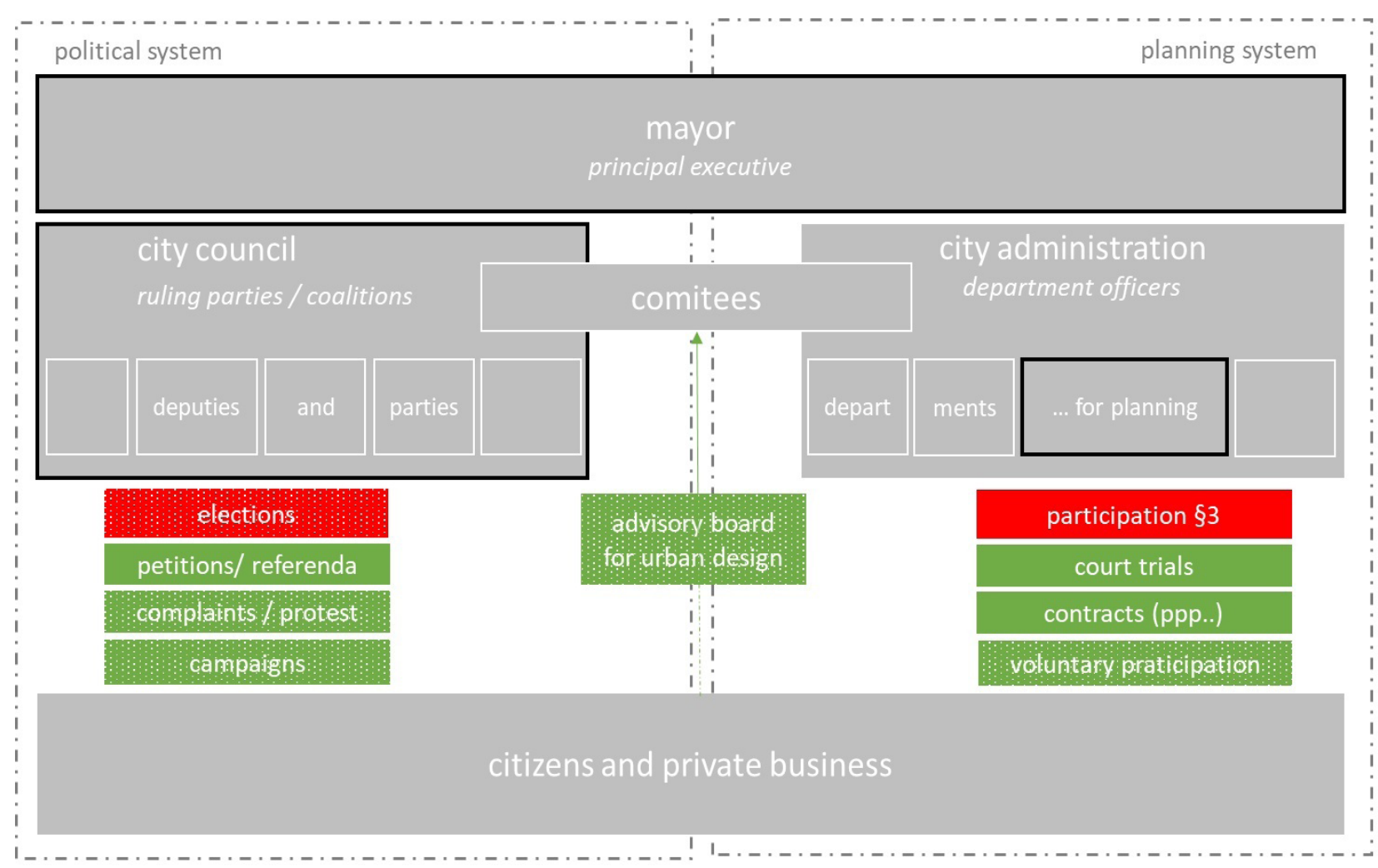

formal opportunities for interaction in urban planning
mandatory - with direct (binding) | indirect (possible) impact on planning

optional - with direct (binding) | indirect (possible) impact on planning

legal stakeholder in planning

Fig. 1. Urban planning institutions in Germany (source: author)

Table 1

Overview of the conflict cases in Bonn (source: Neugebauer et al. 2021, modified by author)

\begin{tabular}{|l|l|l|l|l|}
\hline $\begin{array}{l}\text { Case and } \\
\text { location }\end{array}$ & Duration & Planning specifics & $\begin{array}{l}\text { Repertoire of citizen } \\
\text { participation }\end{array}$ & Outcomes \\
\hline $\begin{array}{l}\text { Bonn: } \\
\text { Viktoriakarree, } \\
\text { Downtown }\end{array}$ & 2012-2018 & $\begin{array}{l}\text { European tender \& PPP-based } \\
\text { detailed land-use planning\& aspired } \\
\text { construction permit. The shopping } \\
\text { mall might replace a mixed uses, } \\
\text { inner-city quarter. }\end{array}$ & $\begin{array}{l}\text { Meetings, petitions and } \\
\text { referendum, protests, } \\
\text { workshops, mandatory } \\
\text { participation }\end{array}$ & $\begin{array}{l}\text { Stalemate between } \\
\text { the activists } \\
\text { and developer/ } \\
\text { landowner }\end{array}$ \\
\hline $\begin{array}{l}\text { Bonn: Railway } \\
\text { Station square, } \\
\text { Downtown }\end{array}$ & $2002-2016$ & $\begin{array}{l}\text { PPP-based detailed land-use } \\
\text { planning\& European tender, statutory } \\
\text { detailed planning \& construction } \\
\text { permit. New constructions replaced } \\
\text { the modernist ensemble in the city. }\end{array}$ & $\begin{array}{l}\text { Meetings, petitions } \\
\text { and referendum, } \\
\text { workshops, mandatory } \\
\text { participation }\end{array}$ & $\begin{array}{l}\text { Construction of } \\
\text { the project with } \\
\text { amendments }\end{array}$ \\
\hline
\end{tabular}


in this area, while the "Masterplan Inner City Bonn" (drafted since 2010 and approved by the city council in 2013) foresaw mixed functionality for the area.

In 2010, developers began to buy plots in the Viktoriakarree expecting the area's commercialization. In 2012, two investors presented their proposals for the development of the area to the City Council's Committee on Economic Affairs: the Austrian-based firm Signa envisioned a demolition of the whole structure and the construction of a shopping mall, and the investor PDP suggested a culture-focused concept. The city administration favored Signa's idea, and the governing Social-Democratic Party (SPD) party together with the Liberal Party (FDP) pushed the decision process forward. The Council's Committee for Planning, however, postponed their decision due to opposition from two other political parties, the Christian Democratic Union (CDU) and the Green Party. The district council of Bonn inner city (Bezirksvertretung Innenstadt) was also against a shopping mall.

Due to this conflict, in March 2014 the City Council decided to carry out a European-wide tender to sell and develop the municipal plots within the Viktoriakaree. The tender included provisions to hold the area open to the public and to preserve the University's library. At the same time, the Council decided to initiate a land-use planning process in which the investor would work out the plan, thus seeking to stimulate investors to develop the area. In May 2014, the City Council elections took place, which led to a change in the ruling coalition: the CDU, Green Party and FDP took over power. While before the elections the CDU had agreed with its coalition partner, the Green Party, on supporting the project, after the elections the latter distanced itself from the project.

The Greens called to preserve the existing milieu of the Viktoriakarree and called for support from citizens "before another part of the historic city center becomes a victim to the profit interest of foreign investors" (press release 2014: Beu/Lohmeyer). By using this specific vocabulary (e.g. 'Kahlschlagsanierung' - urban clearance, 'Profitinteresse'- profit interests) the authors referred back to the aforementioned heavy controversies that characterized West German planning debates in the late 1960s and 1970s. The outcome of these debates was a shift in perception, namely towards the recognition to preserve existing urban structures, their socio-spatial milieus and to empower citizens. By explicitly linking the Viktoriakarree-project to these debates and by approaching the citizens directly, the local politicians were seeking to strengthen their position.

Political support for the project was already shaky at this moment. But the conflict really arose in 2015 when the City Council presented its decision to sell the municipal plots to Signa, which despite the provisions in the tender had repeated a bulky shopping center. Consequently, a citizen initiative, Viva Viktoria, was launched in August 2015 to protect the area against the project. Several other initiatives joined them in staging public protests every Wednesday. They launched a petition for a public referendum that the City Council members of the SPD, the Green Party and The Left Party (against CDU and FDP) joined in December 2015.
In consequence of the referendum result, the decision to sell the municipal land was cancelled and the tender procedure stopped.

The project re-started in 2016, this time with a costly citizen workshop, which Signa left before an agreement between all stakeholder groups could be reached. In parallel, Signa acquired other plots in the Viktoriakarree, thus becoming the dominant property owner. From 2016 onwards, the company halted rental contract extension for local businesses, stoking peoples' fears that Signa intended to ruin the lively atmosphere of the Viktoriakarree in order to increase pressure on officials. By the time of writing, the outcome of the conflict was unclear. While the activists still demand a sensitive renewal of the area, the investor did not publish an alternative to his shopping-oriented proposal yet. The city administration seeks the compromise, but it is caught between the new property pattern and private/ public interests divisions.

\section{Bonn: A new commercial entrance to the city}

The second case in Bonn concerns the development of the railway station's square, which has been a site of renewal and contention since the 1970s. Due to civic protests at that time, the city stopped the already started construction. In the early 2000s, the public authorities decided to give it another try and made a call for expression of interest for European investors. From the eight competitors the City Council selected the project developed by the developer Brune, which consisted of a glass-construction complex with retail spaces. This decision spurred a conflict: By the end of 2002, citizens' initiatives and other lobby groups criticized the project, but above all the planning- and decision-making process. Opponents argued that key decisions had been made before even presenting the project to the public and urged for more participation in the planning process.

Despite the resistance, the City Council gave the formal mandate to the city administration to continue working with Brune on a ppp-based detailed landuse plan. Between 2003 and 2004, the investor in coordination with the city administration further developed their proposal. Although amendments were made and additional forms of participation such as meetings were carried out, the conflict intensified. The public interest groups demanded significant changes, and a group of citizens initiated a public petition against the renewal of the square. Even though the CDU had been a strong supporter of the Brune concept, the party joined the public petition in the course of the campaign for mayoral elections in autumn 2004. In consequences of the referendum results, the City Council cancelled the project in December 2004.

After this 'crash', supporters of the petition (CDU, BBB and Green Party) pushed for a quick restart and proposed to proceed differently. The city organized a costly public workshop with citizens, lobby groups, politicians and city officials between October 2005 and January 2006, to find consensus on key planning objectives. The resulting agreements included maintaining a sufficient distance between the new buildings and the railway station; the reduction or demolition of the Südüberbauung - the unloved 
modernist architecture by Friedrich Spengelin; the creation of a public square as well as the commitment that planning competence must remain with the city and shall not be given to a private investor.

In 2007 the City Council decided to develop the plots of the whole territory separately and an interested investor, GDG, started to work on a project to replace the Südüberbauung for its own cost. In the course of the development, GDG demanded concessions from the city, namely to grant it the land-use concession for the plot as investment protection. The city, however, rejected this request and launched a solely state-run detailed landuse planning process in 2008. At that point various citizen initiatives started to heavily oppose the city. They called for the city to actively support the private investor in their attempt to quickly demolish the unloved Südüberbauung; thereby, however, also opposing the former workshop agreement that the city shall not merely "serve" the interests of private investors.

Yet, the alliance between the activists and the investor broke after the investor presented his design by the end of 2009. Opponents now came back to the agreements of the workshop and systematically criticized the project based on these principles. The agreements of this workshop became a reference point during the whole process. However, all stakeholder groups made selective and shifting use of them conforming with their also shifting interests and positions. Though GDG made several amendments to its project, it could not build consensus and finally dropped the project due to financial problems in 2014. Another investor, Ten Brinke, jumped in, with a new proposal for the Südüberbauung and received the building permission in 2016 in line with detailed land-use plan that had entered into force in 2013. The project is currently under construction, and several activists meanwhile lament about the lost heritage of the once unloved modernist Südüberbauung.

In sum, these detailed insights into two project stories nurture general observations about the stakeholders and their interdependencies in urban renewal planning. Following, I try to compile findings of general interest. Therefore, I draw on the Bonn study as well as on our primary research in the German cities of Essen and Arnsberg ${ }^{7}$ and secondary literature.

\section{5 . The contradictory role of citizen participation} in urban renewal (observation 1).

A first essential observation in this vein is that the citizens' voices and activism matter in German urban renewal planning, however in an ambivalent manner. What do I mean?

The case studies of Bonn, Arnsberg and Essen, show - and that is the first part of observation - that citizen participation is deeply rooted in current renewal planning. The citizens themselves use the multiple opportunities to access urban planning processes, to voice and pursue their interests. Moreover, the local authorities carefully implement the mandatory civic participation (§ $3 \mathrm{BauGB}$ ), and there is also a more or less routinized useof the various voluntary tools of citizen participation. In
Bonn, for instances, two costly citizens workshops were carried out. In the city of Arnsberg and Essen, voluntary participation is regularly used in view of complex and potentially conflictual projects (Interview Fröhlich, Witte, Vielhaber): 'in every project we actually ask who and how we can involve' (Interview Fröhlich 25: $30 \mathrm{~min}$ ). New tools are tested in order to engage with as many citizens as possible and to avoid stuffiness among the participants (Interview Fröhlich, 22: 50 min, Interview Witte, 27: $32 \mathrm{~min}$ ). Several German guidelines also describe and explain the use of theever-evolving toolbox for participation, thus indicating the wide spread of voluntary participation in German renewal planning. The guideline for architectural competitions (BDA, 2014) is an example thereof: issued in 2014 by the German chamber of architects, it recommends the early-stage participation of citizens in any competition. At the municipal level, public authorities propose pro-actively additional citizen participation (like in Arnsberg or Essen) or they are pushed like in the Bonn cases.

This practice and routine of citizen participation seems to alorize the (self)confidence and activism of the citizens. So the German activists show a high self-confidence of their power and a strong awareness of 'their' decision-making rights in urban planning, differently to urban activists in Russia for instance (cf. Neugebauer et al., 2021). At the same time, all interviewed local stakeholders (i.e. politicians, planners and private entrepreneurs) acknowledge the importance of citizens in urban renewal. The conflict stories of Bonn also testify the power of citizens to change the courses of renewal planning, either through direct referenda or indirectly through the local deputies' responsiveness to their causes (cf. Interviewee 5, 22: $36 \mathrm{~min}$ ). Consequently - and in difference to Ukraine and Russia (cf. Neugebauer et al., 2020), the local authorities in Germany do not attempt to undermine the citizens' right to planning information and mandatory participation. The legal obligation for citizen participation matches with the informal agreement to do so. Rather there are some disagreement and splintered routines how local authorities deal with voluntary participation and with some activists' calls for more direct decision-making power in urban planning (cf. Vetter, 2017). Here we see local differences between Bonn, Arnsberg and Essen: the latter show a broader acceptance and routineness with voluntary citizen involvement.

At the same time - and that is the second part of the observation - the German participatory urban renewal planning also reveal ambivalent trends and new challenges.

A first ambivalent observation is that tools and local practices of citizen participation contribute to the reshuffling of political responsibility and accountability in planning. Though planning is per se political, the citizen participation in Germany - and in particular, the tools of voluntary participation - tend to shift key questions of democratic debate from the city council to the planning departments. The background is that the planning departments alone most often choose and configure the

${ }^{7}$ In comparison to the city of Bonn, Essen is as big city of 580,000 inhabitants with a relatively lower prosperity. The city of Arnsberg is a prosperous, medium-sized city of 73,000 inhabitants. Both are also located in the federal state of North Rhine-Westphalia. 
voluntary tools of participation. In doing so, they predefine without any systematic regulation or surveillance the citizens' opportunities to voice and intervene in planning. Consciously or unconsciously, the planners touch and answer the question who is getting the chance of voicing or not. They gain 'silently' a political power and burden respectively, which actually belongs to the city council as local legislative body that has to ensure representativeness and accountability.

This is an overload of planners and a risk to the fairness and democratic legitimacy of renewal planning. Because on the one hand, we see that the scope of voluntary participation in German renewal planning grows and thus the load to decide and design-well each informal participatory event. On the other hand, the challenge is to consider and balance both, the citizens' inequality ${ }^{8}$ in general and the diversity and fluidity of urban activism in particular. With regard to the latter, we may recall the cases of Bonn with the plurality of interests and the instability of activists' positions. In the case of the Bahnhofsvorplatz, for example, the activists forgot about the citizen workshop agreements and asked the planning department to support the investor, and after the decision for demolishing the modernist Südüberbauung, yet other activists started to lament on the cultural loss.

Today, in urban renewal, long-term activism and altruism contrasts with NIMBYism (e.g. Gestring et al., 2014; Mayer, 2000; e.g. Interviewee 5, Interviewee 2). Clear ideological-political agendas clash with ignorance or opposition (e.g. Interviewee 7) and many more. Finally, the political scientist Margit Mayer reconstructed in her research the long-term trend of pluralization and fragmentation within the West German urban activism (Mayer, 2000: 131) ${ }^{9}$. Against this background, the voluntary participation in urban renewal highlights both, the challenge to consider and balance the diversity of activism and societal inequality as well as the ambivalent trend to 'silently' outsource this great challenge from the legitimized and accountable city council to somewhere else.

The second ambivalent finding refers to the contradictory role of urban activism in renewal planning today. The conflict cases in Bonn remind of its negative effects, as the retardation of planning. Moreover, we know several cases where local activism prevented important projects for the good of the many. Margit Mayer (2000:149) explains the "contradictory role" of urban activism as the result of theinternal pluralization of local activism - that came along with the growth of self-confidence among the German activists - and the new structural conditions, i.e. the new institutional opportunities for urban activists. Both developments can turn out negative, in particular when local stakeholders - such as deputies and planners - hold uncritical or simplistic expectations towards citizen participation. In this vein, Angelika Vetter and colleagues (2013: 265) warn of the local misunderstanding of participation as 'consensusmaker'. They plead that 'the majority principle [...] must remain the central and ultimately necessary democratic decision-making rule' at the ground and that 'citizen participation' is a tool'to increase the breadth of the supporting majority’ (ibid.).

Until today, we witness the "high risk" that local minorities politically abuse tools of participation in order to impose their interest on the majority (Vetters et al., 2013: 268). In Bonn, we gained the impression that some activists did so, and also a quote from Essen confirms the threat: 'I was a judge for almost 40 years, and that's why I really try to be neutral. But myself, I am shocked by what is happening in this business [in urban planning]. The louder minorities articulate themselves, the more they succeed' (Interviewee 1, 38: $56 \mathrm{~min}$ ). Unfortunately, there is rarely any study that has researched the impacts of citizen participation in urban renewal in breadth and depth (e.g. Selle, 2018).

Summing up, we witness that citizens and urban activism are important and by now self-evident parts of German renewal planning. All sides use the tools of participation - the legally mandatory and voluntary ones -in a more or less routinized manner. So far, however, citizen participation in planning hasn't brought up easy and final conclusions how to govern urban renewal. Rather, it brings ambivalent trends and new challenges to the fore such as (1) the outsourcing of parliamentary debate to the planning departments and (2) the uncertainty about the un/intended effects participatory planning. The introduction of participatory tools in German urban renewal planning was a necessary step. Instead of a conclusion, however, it elicited and urges for acontinuous, self-critical learning among all stakeholders (Vetter et al., 2013: 268).

6. The little explored dominance of investors in urban renewal (observation 2)

Apart from the citizens, the private entrepreneurs in form of investors and developers shape the governance arrangements in urban renewal planning. Our local interviewees even assess the entrepreneurs and their interests as pre-dominant in renewal planning, at least in the two conflict cases of Bonn (Neugebauer et al., 2021). The mathematical analysis of Bonn's stakeholder networks confirmed very small cliques of decisionmaking: in both planning cases, the cliques include the city administration, local politicians and the investor(s), whereas the citizens and their representatives are not in (Neugebauer et al., 2021a: 39).

In doing so, the investors and developers in Bonn share similar understandings of 'planning effectiveness' and 'participatory planning'. They equate 'planning effectiveness' with the 'reliability of planning'

${ }^{8}$ Jörke (2011) remind of the unevenly distributed resources such as time, knowledge and skills that citizens have to invest in any form of citizen participation, but in particular in the deliberative, voluntary ones.

${ }^{9}$ In her study Margit Mayer observed that "from the 1970s and early 1980s [the urban social] movements exhibited relative coherence and unity in their opposition to urban renewal, in their demands for improved collective consumption" (p.131). In the "1990s [however] an extremely fragmented urban social movement scene" (p. 136) emerged that was fragmented in terms of "pursued interests and repertoire" (p. 138). Also local interviewees report on shifted attitudes among local activists (e.g. interviewee1, 4, 5 and 6). 
(Planungssicherheit), since the latter secures their investments in project planning and development. Similarly, they intersect the concept of 'effectiveness' and 'participation': They acknowledge the need of citizen participation in planning, however reject any aspiration ofcitizens' decision-making in planning with the argument that this would subvert the local parliamentary democracy. The conflict stories in Bonn display how direct decision-making of citizens - the referenda - and the activists' indirect influences on the city council's decisions changed or even stipulated the course of the planning processes. These interferences are threats to the investors' interest in planning effectiveness, i.e. to the investments in planning.

In line with this rationality, the Figures 2 and 3 illustrate for the two Bonn cases the entrepreneurs' specific network management. The figures show - at the level of discussion (lines of blue colour) for example that the city administration and the investors dominate the networks ${ }^{10}$. However, they do in different ways: while the city administration discusses with many different actors, the investors concentrate on small networks. They focus on the city administration and discuss with some few political bodies and local economic actors (such as the Chamber of Industry and Commerce, property owners), but sideline most often the citizens. The reason is that only the formerowns the institutional power to grant building permits and thus the aspired planning and investment security (Neugebauer et al., 2021a: 38). Accordingly, we may assume that the aforementioned empowerment of citizens in urban renewal planning challenges the entrepreneurs' effective and efficient mode of networking in urban renewal planning. So far, however, the scope and quality of any paradigmatic shift within the stakeholder groups of investors and developersis still unexplored.

Today, the opportunities for investors to pursue their interests in urban renewal are manifold and rooted in the local political and planning system. The German systems allow lobbyism and direct talks with the city mayor, deputies and the planning departments. The planning system also offers ppp-based planning instruments (i.e. ppp detailed land-use plans, real estate tenders and urban contracts), which enable the very early voicing of economic interests in planning; these instruments also reduce the parliamentary and public control in favour of the city administration and the mayor who gain greater leeway (cf. Interview 4, Interviewee 8). This may spur suspicion among local citizens (Neugebauer et al., 2021) and nurture the perception of economic predominance in the city. So far, however, we know little details how the investors and developers enforce indeed their interests in planning and which planning instruments, local regimes and planning routines transmit, favour and/or buffer them (Hurk et al., 2020; Groß, 2017: 114 \& 145).
Our case studies remind considering also the diversity of investors that is evident beyond the aforementioned commonalities of shared concepts and practices. The interviewed entrepreneurs show, for example, differentiated sensitivity and interest in the spatial-material and socio-cultural features of urban renewal projects. Though all strive for profitability, they differ with regard to the aspired profit margins and the strategy how and where to reinvest the profits (e.g. Interviewee 3). Some are interested in the local context and design qualities envisioning mid-term benefits (e.g. housing cooperatives, local investors); others are ignorant about this and aspire short-term profitsonly such as some international investors in Bonn.The conflicts cases in Bonn also point tothe different power strategies of entrepreneurs: In the case of the Viktoriakarree, the investor accumulates land property as power resource and bargains with the fear of still stand and degradation. Though not all investors are such 'nasty people' (Interviewee 5: p.11), but partners to 'cooperate trustfully with' (Interviewee 5: p.10, cf. Interviewee 9: p.12), the unpleasant investors in urban renewal would make up app. 50\% (Interview Graf/ Müller, p.11) - at least in big cities such as Bonn and Essen. In contrast to citizens, investors and developers own and use allocative power resources - i.e. money and land property - in pursue of interests.

Summing up, we witness that the private entrepreneurs in terms of developers and investors are broadly perceivedas (pre)dominant actors in German urban renewal. The local planning and political system offer them opportunities to voice their interests. So far however-and that is surprising, we miss an updated and nuanced understanding of the private investors' practices and power in German renewal planning. We know little about the internal diversity of this group, about the differentiated and evolving practices, and local factors such as city size, political regimes, and planning routine - conditioning their role.

\section{Local political regimes in urban renewal}

\section{(observation 3)}

The previous paragraphs mentioned the local political bodies as gatekeepers to and decision-makers in German urban renewal planning. The city council, for instance, launches controls and approves localplanning, and the Bonn conflicts stories show that the city council and local deputies serve especially to the citizens as access points. The latter either use the opportunities of mandatory citizen participation in planning $(\$ 3 B a u G B)$, or they approach local deputies directly (e.g. via petitions and media) and may benefit from the politicians' responsiveness to their causes.

The political responsiveness to citizens is generally rooted in the German mode of local parliamentary democracy (cf. Neugebauer et al., 2021). However, it differs at the ground in dependence on the local political

${ }^{10}$ The width of the line shows the relative frequency of the connections or interactions between the actors, e.g. a multiple discussion. However, the order and graphic arrangement of the actors in the figures are purely random. More details in Neugebauer et al. (2021a: 35).

${ }^{9}$ In her study Margit Mayer observed that "from the 1970s and early 1980s [the urban social] movements exhibited relative coherence and unity in their opposition to urban renewal, in their demands for improved collective consumption" (p.131). In the "1990s [however] an extremely fragmented urban social movement scene" (p. 136) emerged that was fragmented in terms of "pursued interests and repertoire" (p. 138). Also local interviewees report on shifted attitudes among local activists (e.g. interviewee1, 4, 5 and 6). 


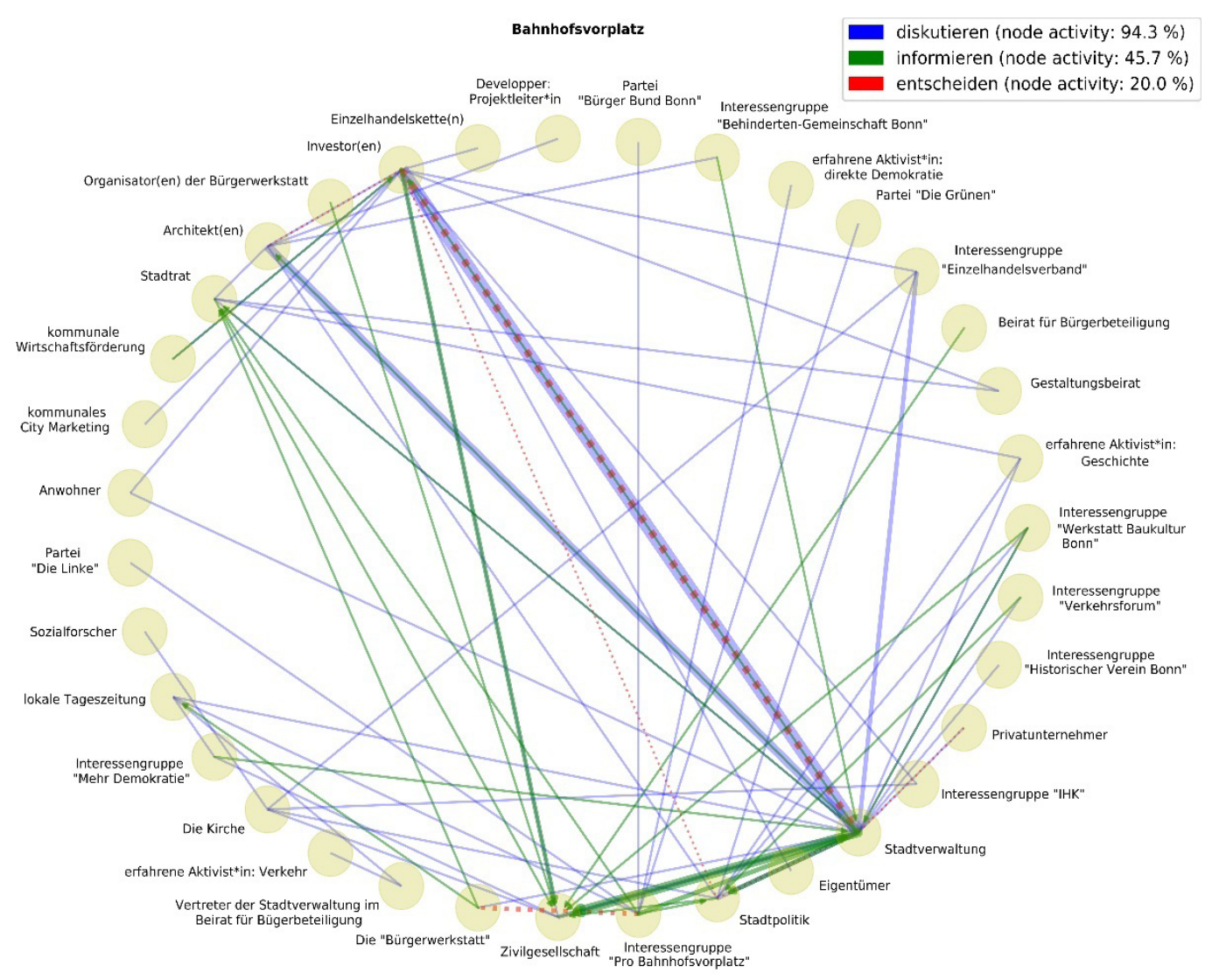

Fig. 2. The local stakeholders' communication networks - the case of Bahnhofsvorplatz (source: Neugebauer et al., 2021a; legend: blue - discussion, red - decide, green - inform)

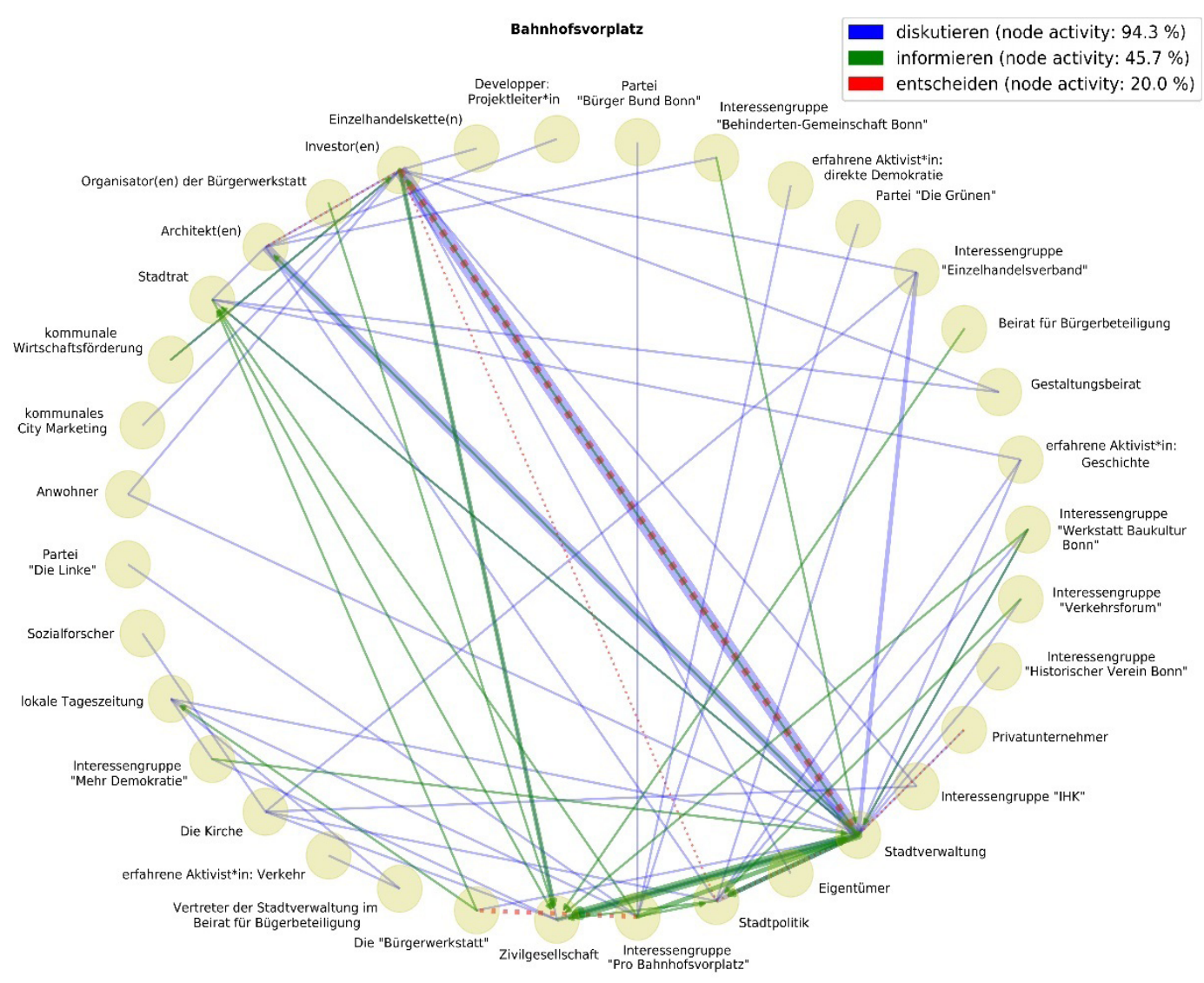

Fig. 3. The local stakeholders' communication networks - the case of Bahnhofsvorplatz (source: Neugebauer et al., 2021a; legend: blue - discussion, red - decide, green - inform) 
regimes. In this vein, the two stories of urban renewal planning in Bonn reveal the power of urban activism in instable local political regimes, which are marked by a high political competition and changing coalitions between parties and/or mayors. Local elections spur here changes in the course of planning; parties and politicians are highly responsive to active citizens, perceiving the activism as seismograph, the renewal planning as arena for electoral campaigning and tools of participation as consensus-makers. Overly reliant on these preassumptions, the local politicians risk to sideline the principles of representiveness and direct accountability as key criteria of parliamentary democracies (cf. Vetter et al., 2013: 268).

In contrast to Bonn, the political regimes in Essen and Arnsberg display a long-standing stability of mayors and party coalitions. Though attempts of activists and deputies exist to overly politicize urban planning and citizen participation (e.g. Interviewee 10: $39 \mathrm{~min}$ ), we witness much less effects thereof due to the much weaker political competition in Arnsberg and Essen. These cases show that political regimes locally differ and that the differences effect on the citizens, the planning departments and the deputies themselves. The latter seem to struggle with the recent formal-institutional changes, especially in contexts of high political competition. That means that even though German deputies broadly accept citizen participation (cf. Vetter et al., 2013), they need to re-position themselves in the evolving German parliamentary democratic system, where active citizens use the new opportunities of "citizen democracy' in an increasing and ever-more selfconfident manner. Urban renewal planning brings this struggle to the fore.

In contrast to the city council, the mayoris apparently the preferred gatekeeper of developers and investors (Groß, 2017; Egner, 2013). Various respondents confirm the normality of office talks or weekend meetings between investors and the mayor (cf. Interviewee 10: $47 \mathrm{~min}$, Interviewee 5: p. 10), and the figures 2 and 3 show the investors' networking focused on the city administration whose head the mayor is. The local deputies (Egner, 2013; Groß, 2017: 144) as well as the urban planners (e.g. Interviewee 1, Interviewee 5, Interviewee 10) underline the mayor's key position and great power in urban policy and planning. As the head of the local authorities, the mayor has a say in all processes of urban renewal such as planning contracts, sales of municipal property, tender processes and agenda setting (cf. Heinelt et al., 2018).

Moreover, also the interplay between the mayor and city council matters for the planning process itself and the stakeholders' opportunities. The mentioned stability and the powerful alliance (coherence) between the ruling party/coalition and the mayor of the same party affiliation facilitate the smooth run of big renewal projects in Arnsberg and Essen (Interviewee 10: $43 \mathrm{~min}$, Interviewee 4: p. 9). In Bonn in contrast, the instable political regime and the opposition between the mayor and ruling coalition increase the opportunities for urban activists as well as the insecurity of investors.

The concepts and routines (i.e. the informal institutions) that the local political representatives share seem to make up another, important part of the opportunity structures in urban renewal. The shared concepts facilitate and hamper respectively the citizens and entrepreneurs' access. For example in Bonn, the local political elites ${ }^{11}$ and the planning department jointly rely on growth and private investments. In both renewal projects, they repeatedly chose instruments of ppp-based planning - real estate tenders and ppp-based detailed land-use planning - in order to structure the planning processes until public protests emerged. The politicians and planners' 'fear of standstill and stagnation' (quote of a local politician, In: Tripar 2017: 22) impeded the local ideas of stock-sensitive planning based on alternative concepts of mixed, but less-profitable uses, as the case of the Viktoriakarree shows. Thus, the shared concept of growth dependency strengthens the position of the international investors in urban planning - at least in the city of Bonn, since collective concepts differ locally.

Summing up, we witness that thecity council and the mayor are important gatekeepers in German renewal planning, who are approached differently: While the investors and developers focus on the mayor, the citizens address the council. In doing so, the locally shared concepts of the local political elites as well as the stability and coherence of the political regimes co-produce and differentiate the stakeholders' opportunities in urban planning. At the same time, especially instable political contexts with high competition make the local politicians struggle with the 'new' tools and practices of participatory and ppp-based urban planning, i.e. they are challenged and also fail to position themselves and to impose consequently the democratic principles of representativeness and accountability.

\section{The power of planning departments in urban renewal (observation 4 )}

According to the survey of 720 deputies in 28 randomized German cities (Tausendpflug et al., 2017: 3), the local politicians perceive the city administration - by a wide margin after the mayor - as the most powerful local player (Groß, 2017). If the mayor and city council block each other due to different party affiliations, the city administration would even benefit from more leeway, so a conclusion of the quantitative survey (ibid: 133). Our qualitative research confirms the tight interdependency between the city administration (i.e. the planning department) and the local policy, yet in a more nuanced manner: planning departments own great responsibilities and duties in urban renewal planning, but act dependent on the stability and coherence of the local political regimes.

In the city of Arnsberg, the urban planning department demonstrates confidence and a powerful position in urban renewal projects, which it draws 
also from their longstanding, stable and trustful cooperation with the local political bodies. The planning department strongly benefits fromthe alliance with the mayor, who dominates the city council for decades, and the cooperation with the city council's committee for planning (Interviewee 4: p. 9, interviewee 10). This is similar in the big-city of Essen. In Bonn, in contrast, the political instability and volatility in committees as well as the blockades between city council and mayor, wear down the city administration. The planning department is caught in the crossfire of investors and attentive citizens as well as confronted with changing political support and missing political alliances. This arrangement demoralizes the urban planning department; the planners are disenchanted, feel helpless and hampered. They express the idea to withdraw from designing any urban renewal project, as long as clear and reliable political positions would be missing (Interviewee 6). Thus, the cases of Bonn, Essen and Arnsberg underline that the relation between politics and planning is key, but less unidirectional than proposed by Groß (2017): political blockades between council and mayor do not result per se in a power gain and strength of city administrations in planning. Rather the opposite may be the case. These governance arrangements within public authorities would deserve more research.

The cases studies of Arnsberg, Essen and Bonn also reveal how the local planning departments use and cocreate their opportunities in urban renewal panning. The design of the planning and communication processes as well as the agenda setting for urban renewal are important approaches thereof.

Decisions on the choice and configuration of the planning instruments pre-define a great deal of the whole planning process and all stakeholders' opportunities to voice their interests. In chapter 2 , I briefly explained the variety of German planning instruments at the disposal of planning departments. In the cases of Bonn - as mentioned already, the public authorities repeatedly chose tender procedures without citizen participation and without strong content specifications to launch the big projects of urban renewal. In the two projects of the Viktoriakarree and Railway Station Square, they configured planning processes, which focused on the investors' interests first and postponed the communication with the local citizens. Alternatively, the choice of a public detailed-land use planning and architectural competition with civic participation, as recommended by the German Chamber of Architects (BDA, 2014), would have offered a more stakeholderbalanced planning process.

The statutory planning instruments highly regulate the stakeholders' interplay and processes of involvement, including a strong level of parliamentary and public control. The voluntary planning instruments, in contrast, offer much more leeway to configure the time, order and scope of stakeholder involvement (e.g. Interviewee 4). They are more flexible to deploy own routines and concepts such as the reliance of big private investments. Though any urban planner bases its practices also on convictions and beliefs (Fainstein et al., 2016: 10), the latter are rarely discusses explicitly and within local authorities. But this was case in Arnsberg, when the local planners, deputies und representatives of the local economy had 'a big discussion about how far one actually intervenes in the open market' by planningand what is the 'fundamental orientation of planning in the city' (Interviewee 4: $28 \mathrm{~min}$ ). The two-days-workshop contributed to a common understanding and conscious local routine that cultivates citizen engagement and relies on public capacities in urban renewal planning. Thus, the contrasting examples of Bonn and Arnsberg show that the choice and configuration of planning instruments matter for the opportunity structures in urban renewal, and that planners (and politicians) take more or less conscious decisions thereon.

Urban planning departments also co-create opportunities through communication. Beyond some tactics $^{12}$, the planning departments communicate strategically and invest time and effort in search of reliable alliances with the city administration (i.e. the other departments), with the city council and many more (Interviewee 4, interviewee 9). A 'good communication culture' would prevent that somebody plays one department off against the other and secures political back up (Interviewee $5 \& 10$ ). An interviewed planer states: 'I have [...] built up a good network, also in the committees and the council. I simply discuss many things beforehand. So before things go pear-shaped, I call the committee chairman, the parliamentary group chairman, the spokesperson for building policy or whoever, just to talk things through with them. Because I know that in the moment I am doing that, their phone rings. And if they are then informed and we say: "This could be a good way", then that is very, very helpful. I think it is absolutely important to do that' (Interviewee 4: $27 \mathrm{~min}$ ). The communication also includes to share knowledge with the partners, e.g. to educate the deputies of the Committee for planning in legal issues (e.g. Interviewee 9). All interviewed planning departments invest in such strategic communication and alliancing. However, the costs and benefits therefor differ in dependence on the local political regimes' stability and coherence as well as on the quality of investment.

Finally, the planning departments develop their opportunities in urban renewal planning through agenda setting (e.g. Interviewee Witte 10 \& 4). The German law (Baugesetzbuch) asks the planning department to identify the needs and propose the contents of future urban development. By picking, rejecting, neglecting or re-loading topics and ideas, the planners unfold 'silently' a great power in urban renewal planning, which is often forgotten (Selle, 2019) and hard to challenge (e.g. Interviewee 2). In consequence, much depends on the individual planner's and planning teams' sensitivity and interest, expertise 
and capacities to come up with a relevant agendafor urban renewal.

Summing up, we witnessthat German planning departments own a wide range of opportunities and also leeway to govern urban renewal. Apart from granting building permits, they use the agenda setting andthe designing of planning processes. In particular, they invest resources, skills and expertise in the strategic communication and alliancing, since the planning departments' opportunities and power depend importantly on the local partnerships. Urban renewal highlights especially the tight, but critical nexus between urban planning and politics. Finally, German planning departments differ, how they use and co-create these 'opportunities to govern. Their self-perceptions ranges from powerful self-confidence and creativity to disenchantment and frustration.

9. Local governance arrangements in renewal planning: Points for discussion

Looking at the urban renewal planning in German cities discussed in the previous chapters, we finally witness differentiated local governance arrangements of the public authorities, private sector and the citizens. The local stakeholder arrangements contrast between conflictive ones - such as in Bonn, where the volatile political regimes, a frustrated planning department and a highly attentive, pluralized and powerful civil society try to 'design' the joint future city - and the more collaborative and peaceful ones in Essen and Arnsberg. The latter display stable alliances between the political stakeholders and planners, who pro-actively invite citizens to planning processes.

The previous chapters also explored how institutions (re)produce and differentiate the stakeholders' opportunities in German renewal planning. The formal political and planning institutions pre-frame opportunities and interdependencies among the actors, and the locally specific informal institutions - in terms of shared concepts, beliefs and routines - explain how local stakeholders use the leeway in urban renewal planning. Whereas in the recent past, the local authorities in Bonn displayed a shared and strong belief in investment-driven urban development and a hesitant attitude towards voluntary tools of citizen participation, the public authorities in Arnsberg developed a conscious routine that cultivates citizen engagement and relies on public capacities in urban renewal planning.

At the same time, our case cities also demonstrate the evolutionary nature of local planning and political routines. So it is in Bonn, where the intense conflicts and citizens' activism in urban renewal planning did not only change and delay the respective projects, but also resulted in the approval of local 'Guidelines for citizen participation Bonn' (Arbeitsgruppe, 2014). The latter were evaluated recently, since the local authorities' interest and awareness has grown therefore (Wiegandt et al., 2020). Thus, local institutions in planning and politics - in terms of routines and concepts as well as regulations - constitute an important explanatory and conditioning factor ${ }^{13}$. They evolve on the ground, e.g. through local conflicts, failures and crisis (Gualini2014), and in response to superordinate trends such as legislative changes.

Finally, the research revealed key interdependencies among the stakeholders of German urban renewal planning, which I consider constitutive for the German context:

First, there is the tight, yet critical interplay within the public authorities - the nexus between the local political bodies - city council and mayor - and the planning departments. The local political regimes, e.g. the (missing) stability and coherence, importantly affect the planning departments' opportunities, costs, power and self-confidence in urban renewal planning. At the same time, the planning departments possess, co-create and gain leeway and opportunities in urban renewal planning that steer or relinquish the democratic control of urban planning processes through the city council.

Moreover - and second, the German renewal planning is marked by the ambivalent, yet little explored nexus between the public authorities, urban activism and private developers/investors. Even though there have been high expectations since decades, we face still today uncertainty and only little interest in learning about the actual local effects of participation and ppp-cooperation in urban renewal planning, e.g. in terms of improved planning performance and strengthened local democracy. However, a closer look at the participatory and cooperative governance arrangements reveals critical challenges that call for further debate, e.g.

- the (over)politization of planers due to the outsourcing of voluntary participation tools to the planning departments;

- the struggling of local politicians to impose the key principles of parliamentary democracy - i.e. representativeness and political accountability - vis à vis the evolving practices of urban activists and private entrepreneurship in urban planning; and

- the broad ignorance about the perceived 'dominant' actor in urban renewal - that are private developers and investors.

Thus, summing up the German experiences of urban renewal planning - also in view of the current planning discussions in Ukraine - we see some promising German experiences with and a 'cultural shift' towards participatory, cooperative and a balanced urban renewal planning. However, urban renewal planning remains a challenging learning process (cf. Vetter, 2017: 27) in search of a 'just and green' urban future. There are neither easy nor final receipts. 


\section{References:}

Arbeitsgruppe Leitlinien Bürgerbeteiligung Bonn (Hrsg.) (2014). Leitlinien Bürgerbeteiligung Bonn. Access mode: https://www.bonn.de/medien-global/rat-undausschuesse/Leitlinien_Buergerbeteiligung_Bonn.pdf.

BDA - Bund Deutscher Architekten (2014). Richtlinien für Planungswettbewerbe RPW 2013. Kommentierung und Handlungsempfehlungen. Access mode: https://www.bda-bund.de/2014/08/richtlinien-fuer-planungswettbewerberpw-2013-2/ (last access: 05.01.2021).

BMU - Bundesministerium für Umwelt, Naturschutz und nukleare Sicherheit ( 2016). Klimaschutzplan 2050 Klimaschutzpolitische Grundsätze und Ziele der Bundesregierung. Download: https://www.bmu.de/publikation/ klimaschutzplan-2050/ (last access: 05.01.2021).

Cruz, N. F. da, Philipp, R., \& McQuarrie, M. (2019). New urban governance: A review of current themes and future priorities. Journal of Urban Affairs, 41(1), 1-19. DOI: 10.1080/07352166.2018.1499416.

Eckhardt, F., \& Elander, I. (2009). Urban governance in Europe. BWV Berliner Wissenschafts-Verlag; 1st edition.

Egner, B. (2013). Stellung und Funktion der Räte im Bundesländervergleich. In Das deutsche Gemeinderatsmitglied. Problemsichten - Einstellungen - Rollenverständnis, eds. Björn Egner, Max-Christopher Krapp und Hubert Heinelt, 17-56. Wiesbaden: Springer VS.

EU Council (2020). The new Leipzig Charter - The transformative power of cities for the common good. Access mode: https://www.europarl.europa.eu/thinktank/en/document.html?reference=EPRS_ATA\%282020\%29659384 (last access: 05.01.2021).

Fainstein, S. S., \& Defilippis, J. (2016). Introduction: The structure and debates of planning theory. In: Readings in Planning Theory: Fourth Edition (pp. 1-18). Wiley.

Fainstein, Susan S. (2016). Spatial Justice and Planning. In Readings in Planning Theory: Fourth Edition (pp. 258-273). Wiley.

Gestring, N., Ruhne, R., \& Wehrheim, J. (2014). Stadt und soziale Bewegungen (Wiesbaden), pp. 7-21.

Groß, M. (2017). Machtstrukturen in der lokalen Politik. In Tausendpfund, Markus \& Angelika Vetter (eds.): Politische Einstellungen von Kommunalpolitikern im Vergleich. Springer VS, pp. 111-150.

Gualini, E. (Hg.) (2014a): Planning and conflict: Critical perspectives on contentious urban developments. London, New York: Routledge.

Healey, P. (1997). Collaborative Planning: Shaping Places in Fragmented Societies. London, Macmillan.

Heinelt, H., Egner, B., \& Richter, T. (2018). Bürgermeister in Deutschland: Problemsichten - Einstellungen Rollenverständnis. Nomos Verlag.

Hurk, M. van den, \& Taşan-Kok, T. (2020). Contractual arrangements and entrepreneurial governance: Flexibility and leeway in urban regeneration projects. In: Urban Studies, 57(16), 3217-3235.

Jörke, D. (2011). Bürgerbeteiligung in der Postdemokratie. Aus Politik und Zeitgeschichte, 1-2, 13-18.

Mayer, M. (2000). Social ovements in European cities: transitions from the 1970s to the 1990s. In A. Bagnasco \&

P. Le Galès: Cities in contemporary Europe, Cambridge University Press (pp. 131-152).

Neugebauer, C., Semenov, A., Shevtsova, I., \& Zupan, D. (2021, in press). Urban planning and civic activism. In: Smyth/ Morris/ Semenov: Russians in Action. Indiana University Press.

Neugebauer, C., Kurzeja, P. (2021a, in press). Netzwerke in der Stadterneuerungsplanung - Interdisziplinäre Herausforderungen und Potenziale ihrer Analyse. In Lore Knapp, J. M. Kötter, P. Kurzeja, C. Michels (eds.): Alles Netzwerk? Ein wissenschaftstheoretischer Vergleich (pp. 27-47).

Neugebauer, C., Semenov, A., \& Denysenko, O. (2020). Urban Activism and Planning in Ukraine and Russia. In Darieva / Neugebauer (2020): Urban Activism in Eastern Europa and Eurasia. Strategies and Practices. DOM Publishers (pp. 138-200).

Schmidt-Eichstaedt, G., Weyrauch, B., \& Zemke, R. (2014). Städtebaurecht - Einführung und Handbuch,

W. Kohlhammer Verlag, Stuttgart (5th edition).

Selle, K. (2019). Ende der Naivität? Öffentlichkeitsbeteiligung in der Stadtentwicklung. Anstiftungen zur Revision. Berlin: vhw-Schriftenreihe 15.

Selle, K. (2018). Planung in der „Status-Quo-Gesellschaft“: zehn skeptische Fragen: Oder: Plädoyer für die Wiederbelebung der Kunst des systematischen Zweifels: ein Vortrag. In Planungneudenken online 2018 (1), pp. 1-16.

Sorensen, A. (2017). New Institutionalism and planning theory. In M. Gunder, A. Madanipour\& V. Watson (Eds.), Routledge Handbook of Planning Theory (pp. 250-263). London, New York: Routlege.

Taşan-Kok, T. (2012). Introduction: Contradictions of Neoliberal Urban Planning. In Tasan-Kok, Tuna \& Baeten, Guy (Eds.), Contradictions of Neoliberal Planning - Cities, Policies, and Politics (pp 1-19). Springer Publishers.

Territorial Agenda 2030, Draft of July 2020. Access mode: https://www.territorialagenda.eu/documents.html (last access: 30.09.2020).

TRIPAR team Aachen (2017). 2nd research report. Urban conflict analysis I-Screening and Conflict biographies.

The case of Bonn, by Daniela Zupan \& Carola Neugebauer. Unpublished manuscript.

Tausendpfund, M., \& Vetter, A. (2012). Politische Einstellungen von Kommunalpolitikern im Vergleich. Springer VS. 


Vetter, A. (2009). Citizens versus Parties: Explaining Institutional Change in
German Local Government, 1989-2008. Local Government Studies, 35(1), 125-142, DOI:
$10.1080 / 03003930802574524$.

Vetter, A., Klages, H., \& Ulmer, F. (2013). Bürgerbeteiligung braucht Verstetigung und Verlässlichkeit: Gestaltungselemente einer dauerhaften und systematischen Bürgerbeteiligung in Städten und Gemeinden. der moderne staat - dms: Zeitschrift für Public Policy, Recht und Management, 6(1), 253-271. https://nbn-resolving.org/ urn:nbn:de:0168-ssoar-59600-0

Vetter, A., \& Hoyer, Z. (2016): Bürgerschaft, Politik und Verwaltung: Drei Perspektiven auf Bürgerentscheide und ihre Wirkungen. Zeitschrift für Parlamentsfragen, 47(2), 349-368.

Vetter, A. (2017). Beteiligungskulturen und Bürgerbeteiligung. In: Tausendpfund, Markus \& Angelika Vetter (eds.): Politische Einstellungen von Kommunalpolitikern im Vergleich. Springer VS, pp. 415-457.

Wiegandt, C.-C., \& Lobeck, M. (2020). Evaluation von Beteiligungsprozessen in der Stadt Bonn. Access mode: https://www.bonn.sitzung-online.de/public/vo020?0--attachments-expandedPanel-content-body-rows-1-cells-2-celllink\&VOLFDNR=5389\&refresh=false.

\section{List of cited interviews (anonymised):}

Interviewee 1: member of the advisory board (2020)

Interviewee 2: local activist (2020)

Interviewee 3: expert advisor of housing companies and association (2020)

Interviewee 4: head of planning department (2020)

Interviewees 5: the head of planning department and the head of land-use planning (2020)

Interviewee 6: head of planning department (2017)

Interviewee 7: urban activist (2017)

Interviewee 8: former head of planning department and currently external expert in the field

Interviewee 9: head of land use-planning section (2020)

Interviewee 10: senior expert in the city planning department for sustainable development (2020) 